\title{
Клінічний випадок хірургічного лікування анаеробної неклостридіальної поширеної флегмони лівої нижньої кінцівки
}

\begin{abstract}
У практиці хірурга трапляються клінічні ситуації, коли захворювання, об’єм його ускладнень і навіть виконання швидких, активних і радикальних дій дають усвідомлення “туманної” перспективи подальшого виживання пацієнта. I чим більший досвід у лікуванні такої категорії хворих, тим більші сумніви тривожать лікаря в перші хвилини критичної оцінки ситуації. Разом 3 тим, той же досвід дозволяє хірургу швидко мобілізуватися і прийняти єдиновірне, на його думку, рішення, яке дозволяє зупинити процес ураження та повернути хворобу в протилежний бік - поступового видужання. Представлено власне спостереження, особливості клініки, діагностики, хірургічного лікування та подальшої тактики ведення пацієнта з поширеною флегмоною лівої нижньої кінцівки.
\end{abstract}

Ключові слова: флегмона; анаеробна неклостридіальна інфекція; хірургічне лікування

У хірургічне відділення № 1 Університетської лікарні за направленням із районної лікарні 17.10.2019 р. госпіталізований пацієнт П., 37 років із скаргами на біль у ділянці лівого стегна та гомілки, неможливість виконувати згинальну функцію в коліні, загальне ослаблення, наявність обширної рани на стегні та гомілці з гнійними виділеннями та неприємним запахом.

3 анамнезу виявлено, що пацієнт під час крівлі впав з даху 17 вересня, після чого не міг ходити. По допомогу в перші дні не звертався. Госпіталізований в районну лікарню 07.10.2019 р., тобто на 21 день від падіння, де йому провели первинну хірургічну обробку з розсіченням та некректомією м'яких тканин стегна. 17.10.2019 р. хворого, враховуючи погіршення стану, розвитку сепсису та у зв’язку з потребою повторного адекватного хірургічного лікування перевели в Університетську клініку.

При огляді стан хворого тяжкий, притомний, контактний, адекватний, дещо загальмований, нор-

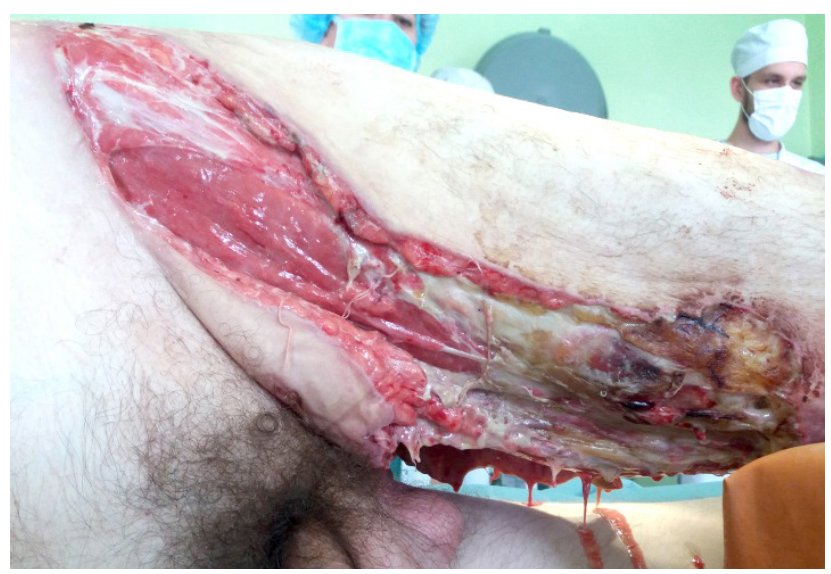

Рис. 1. Вигляд стегна спереду. мостенічної тілобудови, задовільного живлення, шкірні покриви бліді, над легенями справа та зліва дихання везикулярне. Діяльність серця ритмічна, тони ясні, звучні; пульс - 98/Хв, АТ 100/60 мм рт. ст.; живіт без особливостей; випорожнення добу тому, сечопускання катетером, діурез до 1 літра за добу.

При локальному огляді на передній поверхні лівої гомілки від верхньої до нижньої третини відсутність шкіри та підшкірножирової клітковини. М'язи передньої групи без фасцій рожевого кольору з ознаками грануляцій та ділянками некрозу в нижній третині (рис. 1).

По задній поверхні стегна шкіра та підшкірна клітковина відсутня на значній частині, у верній третині некротично змінена сіро-жовтого кольору, задня група м’язів має вигляд “вареного м’яса”. По задній поверхні лівої гомілки по всій довжині від підколінної ямки до ступні некроз шкіри та підшкірно-жирової клітковини від 4 до 8 см завширки (рис. 2).

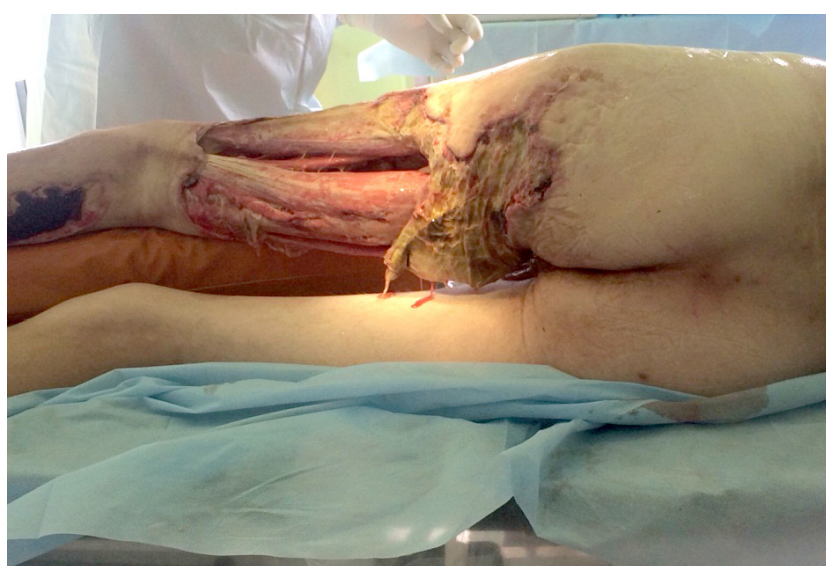

Рис. 2. Вигляд стегна та гомілки ззаду. 
У ЗАК - Нв - 101 г/л, Ер - 2,6 Т/л, КП - 1,1, Ле - 5,8 Т/л, ШОЕ - 55 мм/год, п - 6, С - 64, Е - 1, Л $-27, \mathrm{M}-2$.

У ЗАК виявлено білок - 1,4 г/л, Ер - 28-38 в п. 3, Ле - 1-24 в п. з, слиз.

В БАК - альбуміни - 21,82, заг. білок - 60,52, інші показники в межах норми.

Коагулограма - ознаки гіперкоагуляції.

Враховуючи тяжкість стану, стабільність ситуації, вирішено провести передопераційну підготовку, що включала катетеризацію підключичної вени, корекцію водно-електролітного, білкового обміну, профілактику септичного шоку після масивної некректомії, що планується хворому, антибіотикотерапію широкого спектра дії, після чого хворому виконано операційне втручання.

18.10.2019 р. - операція (повторна хірургічна обробка флегмони, фасційектомія, некректомія). Враховуючи тяжкість стану хворому виконано епідуральну анестезію. Гострим шляхом висічено всі некротично змінені тканини передньомедіальної та задньої поверхонь лівого стегна та задньої поверхні лівої гомілки в межах здорових тканин. 3 кожного м'яза передньої та задньої груп м'язів стегна видалено залишки фасціальних нашарувань до появи кров'янистої роси на м’язах. Візуалізувати сідничний нерв та крупні судини було надто складно та винятково пальпаторно. Всі вони були вкриті грануляційною тканиною, тому кожен рух потрібно було кілька раз перевіряти (рис. 3,4$)$. Незважаючи на відсутність масивної артеріальної кровотечі разом із тканинами та внаслідок пропотівання крові після фасціотомії, загальна втрата крові у хворого склала до 500 мл, ми це передбачили ще до операції, тому для хворого замовили два гемакони крові з перевіркою групової сумісності донора та реципієнта.

Одночасно пацієнту було проведено дослідження на маркери сепсису: с-реактивний білок 155,45 mg/l (при нормі < 5,0); прокальцитонін $0,800 \mathrm{ng} \mid \mathrm{ml}$ (норма до 0,05), що свідчить про невисокий ризик сепсису (від 0,5 до 2,0).

Взято матеріал на бакпосів та чутливість до антибіотикотерапії. Слід зауважити, що впродовж усього періоду лікування проводили щотижневі бакпосіви та спостерігали постійну зміну бактеріальної флори, що, відповідно, потребувало корекції в антибіотикотерапії. На нашу думку, в такій ситуації має місце полібактерійність ураження, яка змінювалася відповідно до дії того чи іншого антибіотика на флору в рані. Так, якщо на 3 добу виявлено ріст Staph. aureus, чутливого до левофлоксацину, моксифлоксацину, лінезоліду, ванкоміцину та через 7 днів після операції

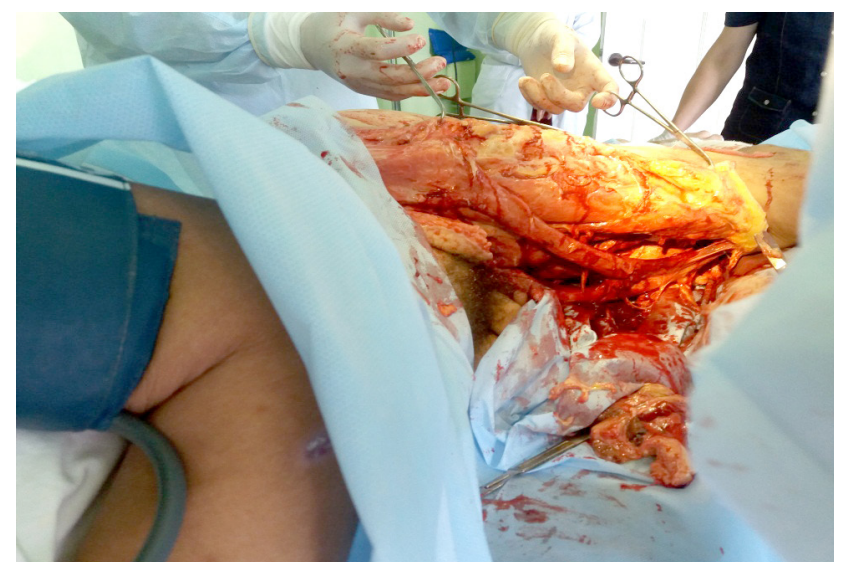

a

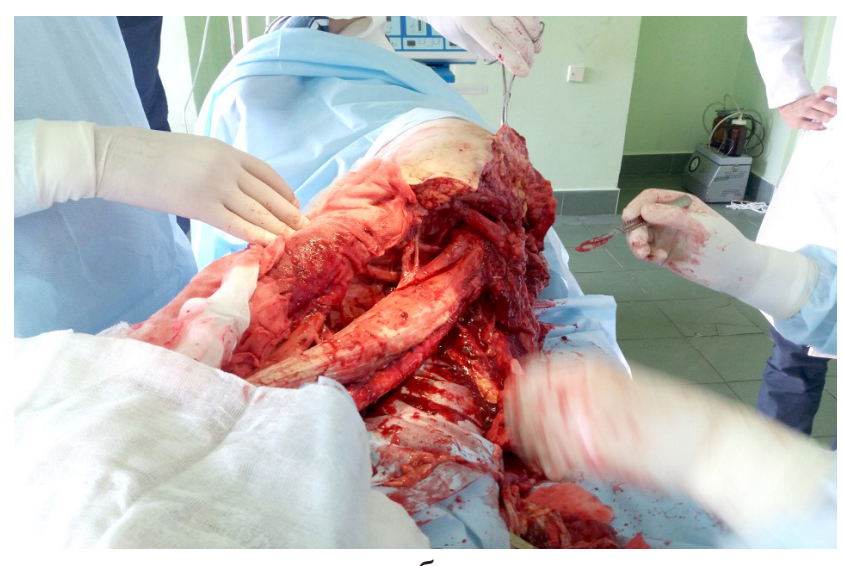

б

Рис. 3. Некректомія передньої (а) та задньої (б) поверхонь стегна.

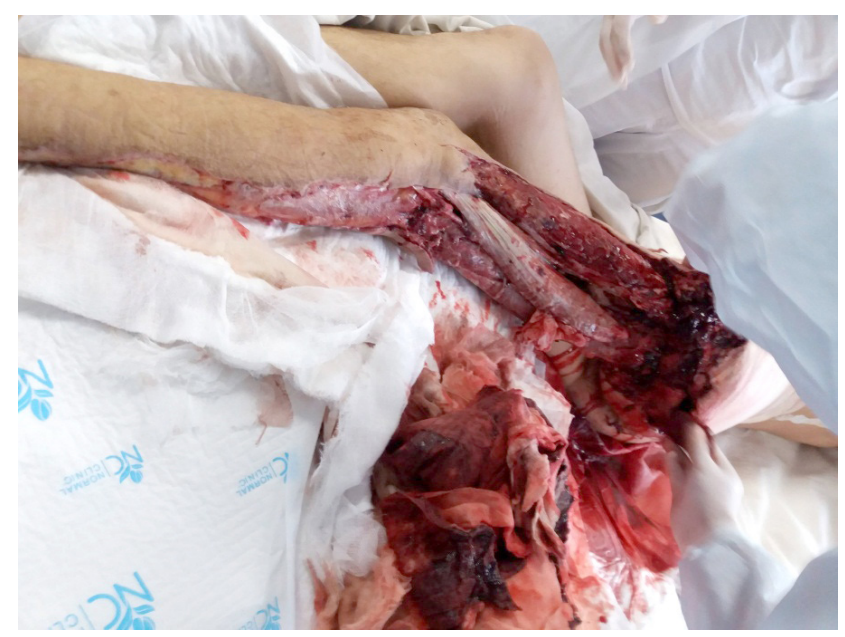

Рис. 4. Вигляд рани після хірургічної обробки.

в рані висіяно Acinetobacter, не чутливий до меропенему, цефтазидиму, піперациліну, а ще через 15 діб виявлено Enterobacter, не чутливий до меропенему, левофлоксацину, піперациліну, цефоперазону. Враховуючи таку картину, перед хірур- 
гом стоїть питання, який антибіотик призначити в перші години госпіталізації хворого із вказаною патологією. Досвід багаторічного лікування хворих із ускладненим цукровим діабетом та гнійними ранами, де кожному хворому проводиться дослідження мікрофлори рани, дозволяє, на нашу думку, емпірично призначити антибіотики широкого спектра дії, що впливають як на грампозитивні, так і грамнегативні аеробні та анаеробні бактерії, а саме меропенем, фторхінолони, піперацилін-тазобактам, лінезолід із подальшою їх корекцією після постійного моніторингу бактеріальних досліджень. Добрий ефект дає поєднання їх 3 метронідазолом.

Завдяки багатовекторному підхіду до лікування як хірургів, так і анестезіологічної бригади, адекватній післяопераційній профілактичній протишоковій терапії, антибіотикотерапії, корекції білкового обміну, переливанню одногрупної однорезусної еритроцитарної маси, свіжозамороженої плазми вже на 3 добу пацієнта перевели із ПIТ ВАІТ для продовження лікування в хірургічне відділення. Щоденно виконували перев'язки, які, однак, потребували до 6 доби введення наркотичних середників із переходом на звичайні знеболювальні препатати.

На 3 добу візуально рани повністю очистились (рис. 5-7). 34 доби впродовж двох тижнів для зменшення об'єму рани, зниження больового синдрому та для активації росту грануляційної тканини ми провели закриття ранових дефектів ліофілізованою ксенодермошкірою свині. Слід зауважити, що весь цей період при перев'язках частина такої шкіри не прижилася, що потребувало щоденного накриття рани новими фрагментами, що разом з тим давало значний позитивний результат (рис. 8).

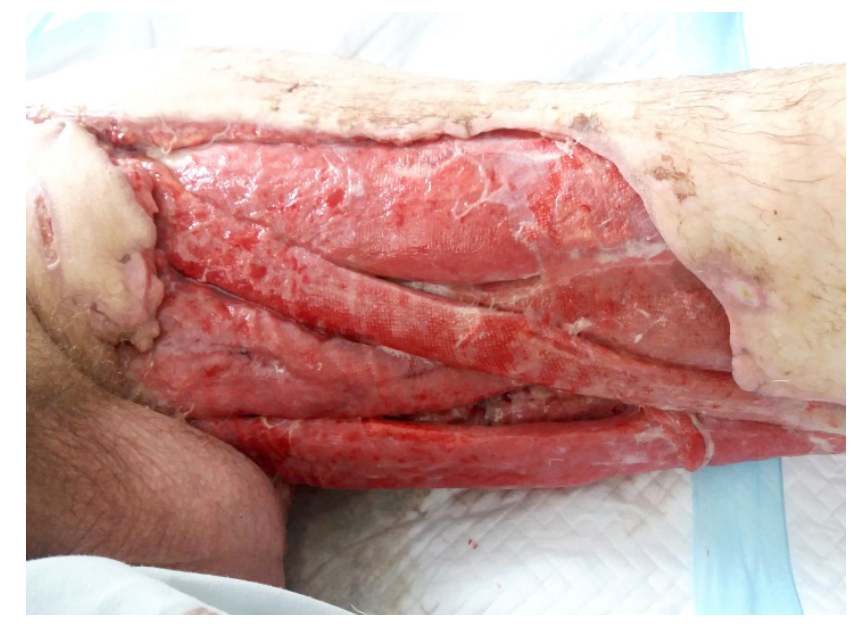

Рис. 5. Рана медіальної поверхні стегна.

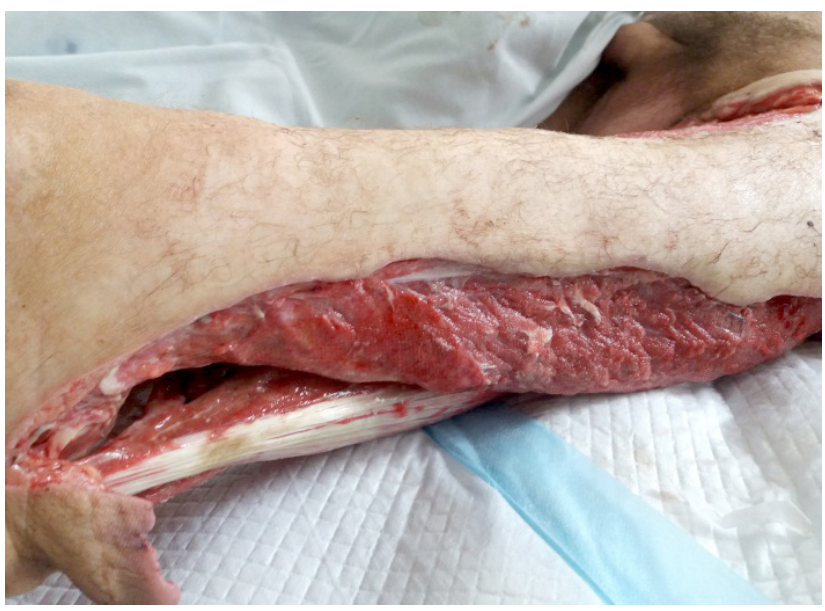

Рис. 6. Рана задньої поверхні лівого стегна.

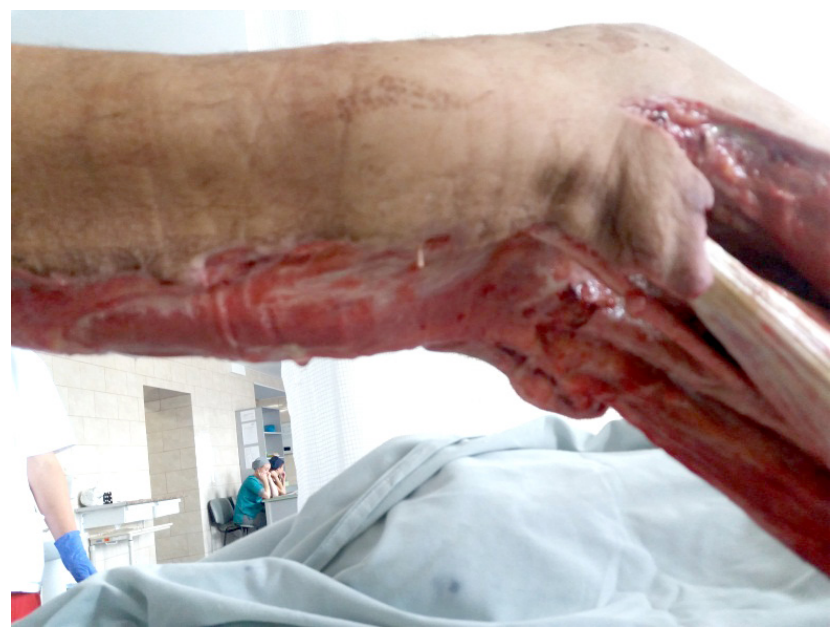

Рис. 7. Рана гомілки.

У хворого значно зменшився больовий синдром, з'явився апетит, нормалізувалась температура тіла. Незважаючи на інтенсивне збалансоване харчування, за наявності великого об'єму рани пацієнт всеодно худнув. Однак це мало позитивний вплив власне на кінцівку, оскільки зменшення в об’ємі мязової маси в ділянці гомілки та стегна дозволило нам провести на 10 добу накладання вторинних швів на рану з майже повним закриттям дефекту гомілки, підколінної ямки та частково дефектів шкіри сідниці (рис. 9).

Звичайно, в післяопераційному періоді в міру загоєння рани ми спостерігали розвиток контрактури в колінному суглобі, що супроводжувалося тяжкістю функції розгинання та обмеженням повної рухомості. Для профілактики цього неминучого ускладнення пацієнту щоденно виконувались примусові розгинальні рухи з накладанням ваги на передню поверхню кінцівки з поступовим ії̈ збільшенням (рис. 10).

Через 18 діб після комплексного лікування у пацієнта повністю відсутній больовий синдром, 


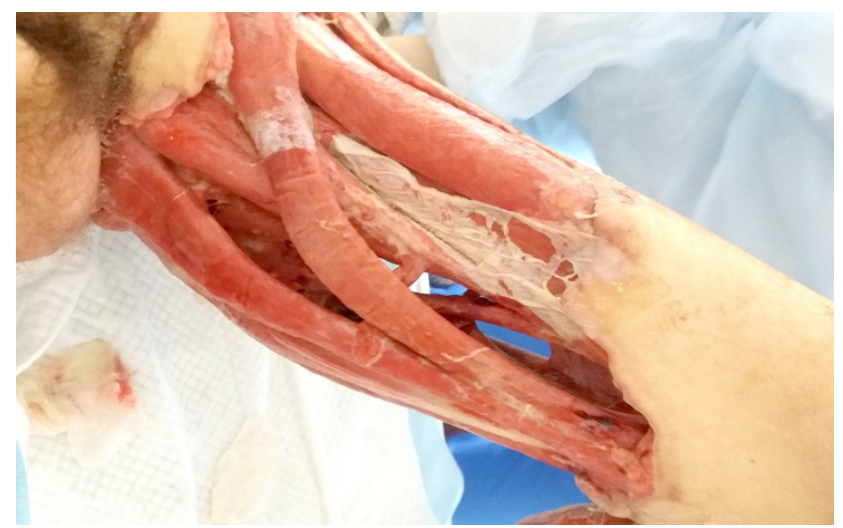

a

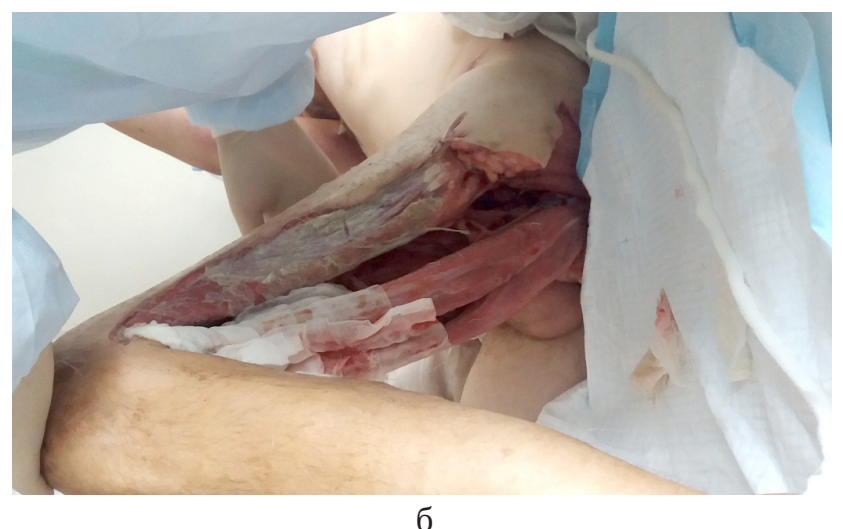

Рис. 8. Вигляд ксеношкіри на ранах під час перев'язки.

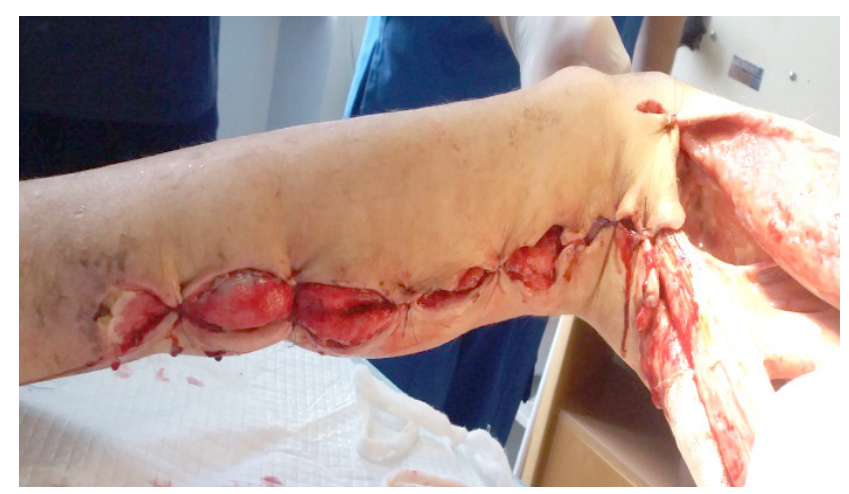

a

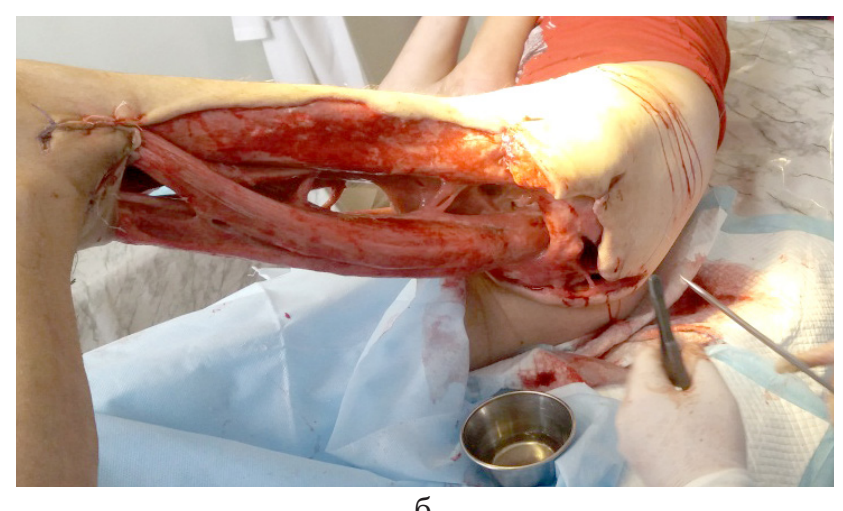

Рис. 9. Накладання вторинних швів на рани гомілки, підколінної ямки та гомілки.

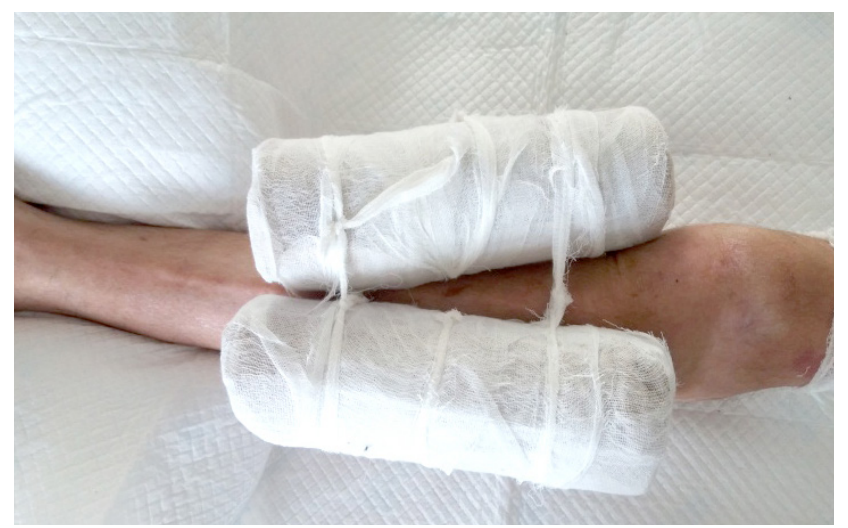

Рис. 10. Профілактика контрактур.

організм адаптувався до об’єму рани, хворий в ліжку активний, при сторонній допомозі поступово стає на ноги.

Тому наступним завданням було сприяти злипанню м’язів передньої та задньої груп стегна, адже за нашими спостереженнями саме рухомість цих м'язів не давала ксеношкірі триматися на м’язах, а, отже, це завадить нам у подальшому провести автодермопластику власними такнинами. За допомогою нової перфорованої експериментальної шкіри свині ми фіксували м'язи по всій окружності стегна, однак на 3 добу вона розмокала і відривалася по одному з країв (рис. 11).

Така ситуація наштовхнула нас на думку застосувати поліпропіленову сітку українського виробництва “Арматура” для фіксації всіє групи м’язів між собою. М’язи між собою додатково зшивалися капроновими нитками № 3 за допомогою вузликових швів. При цьому умовою було повне очищення рани, відсутність в ній патогенної флори (рис. 12).

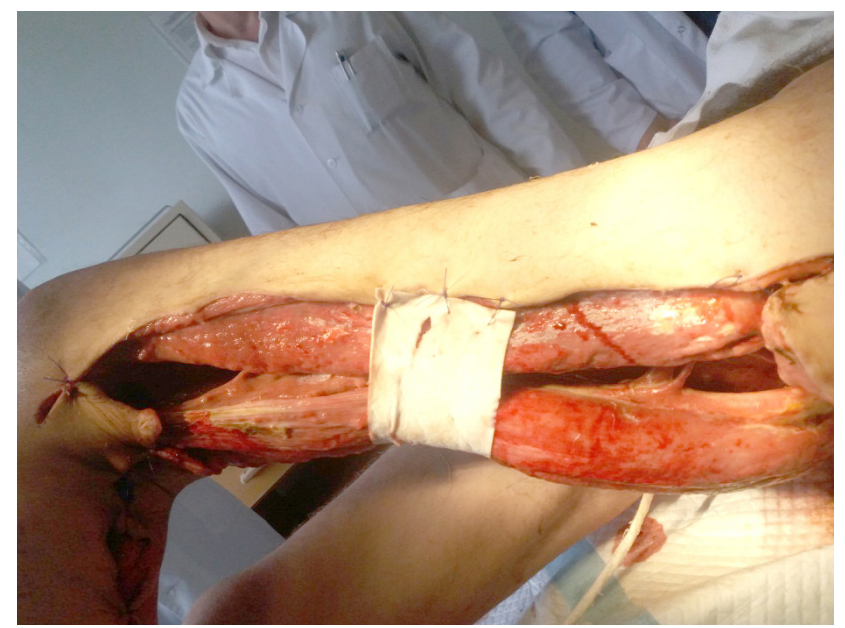

Рис. 11. Фіксація м’язів за допомогою експериментальної шкіри свині. 


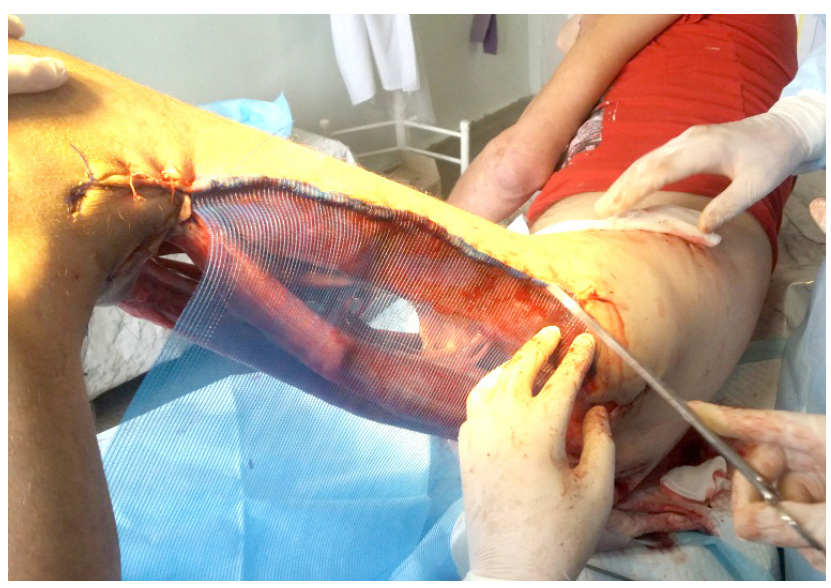

a

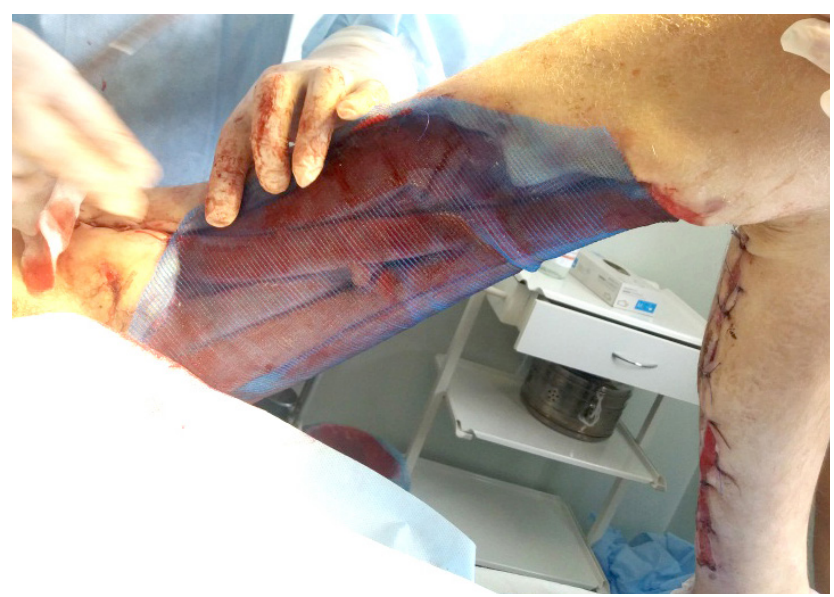

б

Рис. 12. Циркулярна фіксація м’язів гомілки поліпропіленовою сіткою до країв шкіри.

Щоденно проводили перев’язки, кожні 2-4 години хворий постійно орошував рану за допомогою розбризкувача розчинами декасану та хлоргексидину, і через 2 тижні, тобто через 32 дні від першого операційного втручання, нам вдалося виконати першу автодермопластику за Тіршем власними клаптями шкіри. Для цього ми не забирали весь поліпропіленовий трансплантант, а залишили середню його частину для подальшого утримування м'язів у злиплому стані (рис. 13).

Через 2 тижні хворого виписали із стаціонару для продовження реабілітації в районній лікарні. Після активної реабілітації в районній лікарні, що включала дозовану ходьбу, масаж, фізіотерапевтичні процедури, пацієнт госпіталізований для повторної автодермопластики ділянок дефекту, де був залишений поліпропіленовий трансплантант та дрібних ділянок, де власна шкіра не прижилася (рис. 14). На даний час пацієнт в повною мірою виконує згинальні та розгинальні рухи в кінцівках, ходить самостійно.

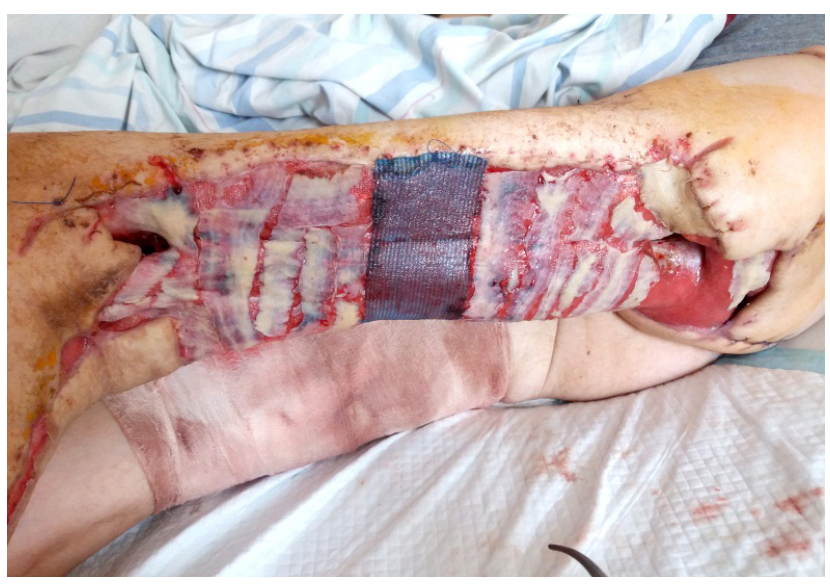

Рис. 13. Автодермопластика (1-ша доба).

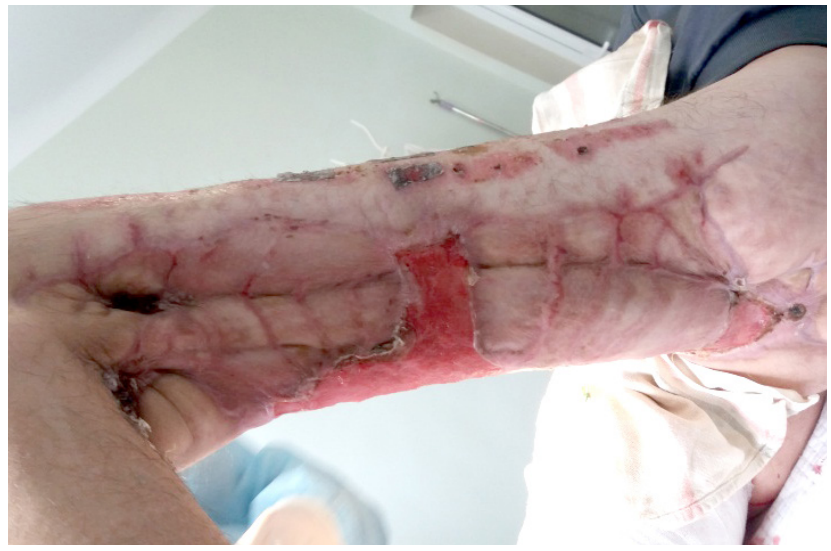

a

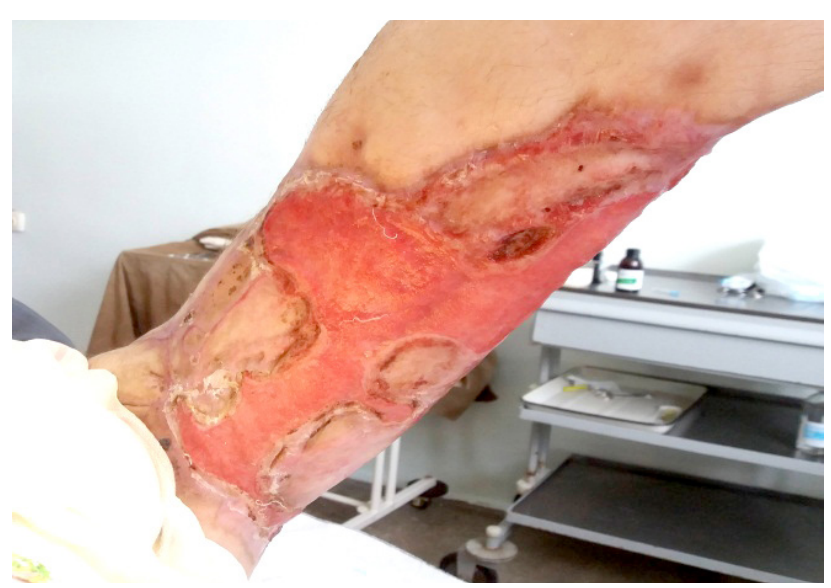

б

Рис. 14. Вигляд рани через 4 місяці.

На 3 добу від повторної госпіталізації в стаціонар після підготовки рани виконано повторну автодермопластику (рис. 15).

Хворого на 14 добу від повторної госпіталізації в задовільному стані виписали із стаціонару для фізіотерапевтичної реабілітації за місцем проживання. 


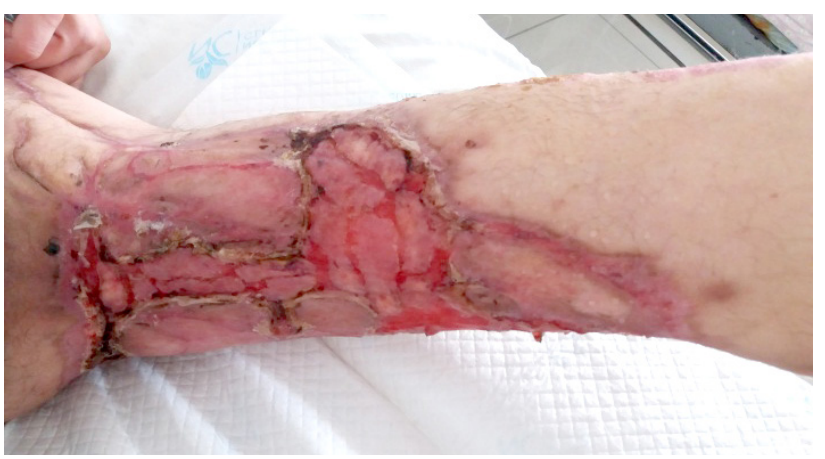

$\mathrm{a}$

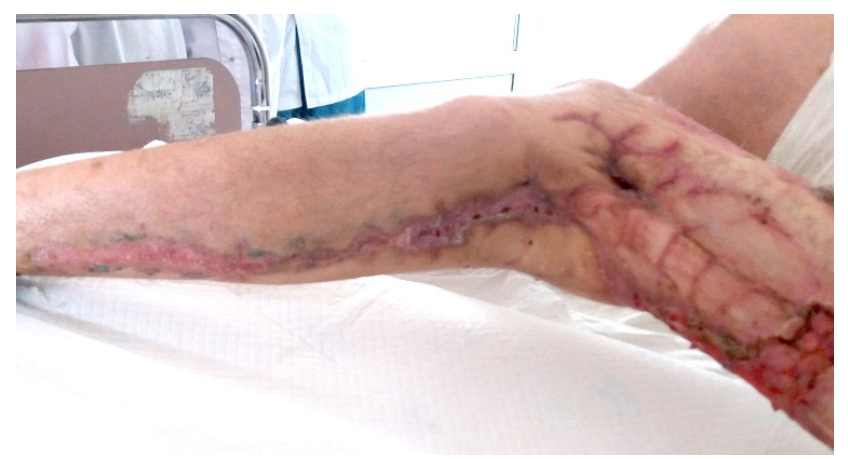

б

Рис. 15. Вигляд рани після повторної автодермопластики на 5 добу та кінцівки загалом.

Висновки. 1. Лікування анаеробної неклостридіальної флегмони у хворих $є$ надзвичайно складною проблемою сучасної хірургії, на превелике щастя зустрічається не так часто, однак вимагає негайного комплексного підходу до лікування та мобілізації багатьох спеціалістів для досягнення позитивного успіху.

2. Дана клінічна ситуація та позитивний ефект від лікування дають безперечний життєвий досвід у подальшому лікуванні будь-яких гнійних

\section{СПИСОК ЛІТЕРАТУРИ}

1. Кондратенко П. Г. Хирургическая инфекция : практ. руководство / П. Г. Кондратенко, В. В. Соболев. - Донецк, 2007. -512 c.

2. Стець М. М. Особливості перебігу анаеробної неклостридіальної флегмони у хворих похилого віку з коморбідними станами на тлі цукрового діабету / М. М. Стець // Шпитальна хірургія. - 2014. - № 4. - С. 78-80.

3. Атиповий перебіг анаеробної неклостридіальної флегмони у хворих похилого віку / М. М. Стець, Т. М. Галига, С. Л. Кіндзер, В. Г. Дубина // Шпитальна хірургія. - 2014. № 1. - С. 69-71.

\section{REFERENCES}

1. Kondratenko, \& P.G., Sobolev, V.V. (2007). Khirurgicheskaya infektsiya: prakt. rukovodstvo [Surgical infection: practical guide]. Donetsk [in Ukrainian].

2. Stets, M.M. (2014). Osoblyvosti perebihu anaerobnoi neklostrydialnoi flehmony u khvorykh pokhyloho viku z komorbidnymy stanamy na tli tsukrovoho diabetu [Peculiarities of anaerobic nonclostridial phlegmon in elderly patients with comorbid conditions on the background of diabetes mellitus]. Shpytalna khirurhiia Hospital Surgery, 4, 78-80 [in Ukrainian].

3. Stets, M.M., Halyha, T.M., Kindzer, S.L., \& Dubyna, V.H. (2014). Atypovyi perebih anaerobnoi neklostrydialnoi flehmony u khvorykh pokhyloho viku [Atypical course of anaerobic nonclostridial phlegmon in elderly patients]. Shpytalna khirurhiia Hospital Surgery, 1, 69-71 [in Ukrainian]. ускладнень мяких тканин.

3. Застосування активної хірургічної тактики та комплексного підходу до лікування дозволило в досить короткий час стабілізувати стан пацієнта та в подальшому повністю відновити функцію кінцівки.

4. Повна реабілітація таких ускладнень досить тривала, вимагає багато сил, енергії, витривалості та витримки пацієнта, а також значних фінансових витрат.

4. Особливості хірургічної обробки та фіксації шкірного клаптя після малих ампутацій у хворих з синдромом стопи діабетика / Ю. М. Футуйма, А. Д. Беденюк, І. І. Смачило [та iн.] // Acta Medica Leopoliensia. - 2018. - № 2, T. 24.

5. An analysis of outcomes of reconstruction or amputation after leg-threatening injuries / M. J. Bosse, E. J. MacKenzie, J. F. Kellam [et al.] // N. Engl. J. Med. - 2002. - Vol. 347. P. 1924-1931.

6. Richmond N. A. Topical and biologic therapies for diabetic foot ulcers / N. A. Richmond, A. C. Vivas, R. S. Kirsner // Med. Clin. North Am. - 2013. - Vol. 97. - P. 883-898.

4. Futuima, Yu.M., Bedeniuk, A.D., Smachylo, I.I., Burak, A.Ye., \& Pavlyshyn, A.V. (2018). Osoblyvosti khirurhichnoi obrobky ta fiksatsii shkirnoho klaptia pislia malykh amputatsii u khvorykh z syndromom stopy diabetyka [Peculiarities of surgical treatment and fixation of the skin flap after small amputations in patients with diabetic foot syndrome]. Acta Medica Leopoliensia, 24, 2 [in Ukrainian].

5. Bosse, M.J., MacKenzie, E.J., Kellam, J.F., Burgess, A.R., Webb, L.X., Swiontkowski, M.F., ..., \& Castillo, R.C. (2002). An analysis of outcomes of reconstruction or amputation after legthreatening injuries. N. Engl. J. Med., 347, 1924-1931.

6. Richmond, N.A., Vivas, A.C., \& Kirsner, R.S. (2013). Topical and biologic therapies for diabetic foot ulcers. Med. Clin. North Am., 97, 883-898.

Отримано 04.06.2020 
A. D. BEDENIUK, YU. M. FUTUYMA, I. S. KULYANDA, O. M. GUSAK, A.YE. BURAK, I. I. LOYKO

I. Horbachevsky Ternopil National Medical University

\title{
CLINICAL CASE OF SURGICAL TREATMENT OF ANAEROBIC NON-CLOSTRIDIAL WIDESPREAD PHLEGMON OF THE LEFT LOWER LIMB
}

There are clinical situations in life of any surgeon, when the disease, the extent of its complications and even the implementation of rapid, active and radical actions give awareness of the "vague" prospects for further survival of the patient. And the greater the experience is in the treatment of this category of patients, the more significant doubts worry the doctor in the first minutes of a critical assessment of the situation. However, the same experience allows the surgeon to quickly mobilize and make, in his opinion, the right decision that can stop the process of defeat and turn the disease into the opposite direction of gradual recovery. The own observation, features of clinical presentation, diagnosis, surgical treatment and the subsequent tactics of management of the patient with the widespread phlegmon of the left lower extremity are presented.

Key words: phlegmon; anaerobic non-clostridial infection; surgical treatment.

А. Д. БЕДЕНЮК, Ю. М. ФУТУЙМА, И. С. КУЛЯНДА, О. М. ГУСАК, А. Е. БУРАК, И. И. ЛОЙКО

Тернопольский национальный медицинский университет имени И. Я. Горбачевского МОЗ Украины

\section{КЛИНИЧЕСКИЙ С.УЧАЙ ХИРУРГИЧЕСКОГО ЛЕЧЕНИЯ АНАЭРОБНОЙ НЕКЛОСТРИДИАЛЬНОЙ РАСПРОСТРАНЕННОЙ ФЛЕГМОНЫ ЛЕВОЙ НИЖНЕЙ КОНЕЧНОСТИ}

\begin{abstract}
В жизни любого хирурга бывают клинические ситуации, когда заболевание, объем его осложнений и даже выполнения быстрых, активных и радикальных действий дают осознание “туманной” перспективы дальнейшего выживания пациента. И чем больше опыт в лечении такой категории больных, тем более существенные сомнения тревожат врача в первые минуты критической оценки ситуации. Вместе с тем, тот же опыт позволяет хирургу быстро мобилизоваться и принять верное, по его мнению, решение, которое позволяет остановить процесс поражения и вернуть болезнь в противоположную сторону - постепенного выздоровления. Представлены собственное наблюдение, особенности клиники, диагностики, хирургического лечения и дальнейшей тактики ведения пациента с распространенной флегмоной левой нижней конечности.
\end{abstract}

Ключевые слова: флегмона; анаэробная неклостридиальная инфекция; хирургическое лечение. 